\title{
Pests and Diseases Associated with Yam Bean (Pachyrhizus erosus) Cultivation at Farmers' Levels in the Central Region of Benin
}

\author{
Amoussatou Bouraïma ${ }^{1}$, Rachidatou Sikirou ${ }^{1}$, Bruno Zocli ${ }^{1}$, Vincent Ezin ${ }^{2}$, Sètondji Alban \\ Paterne Etchiha Afoha ${ }^{3 *}$, Léopold Simplice Gnancadja ${ }^{4}$, Adolphe Adjanonhoun ${ }^{5}$, Kerstin Hell ${ }^{6}$ \\ ${ }^{1}$ Laboratory of Crop Protection (LDC), National Institute of Agricultural Research of Benin (INRAB), Benin \\ ${ }^{2}$ Department of Crop Sciences, Faculty of Agriculture, University of Abomey-Calavi, Benin \\ ${ }^{3}$ Laboratory of Biotechnology, Genetic Resources and Animal and Plant Breeding of the National University of Sciences, Technologies, Engineering and \\ Mathematics, Benin \\ ${ }^{4}$ Faculty of Sciences and Technics, University of Abomey-Calavi, Benin. \\ ${ }^{5}$ Center of Agricultural research (CRA-Sud), National Institut of Agricultural Research of Benin (INRAB), Benin \\ ${ }^{6}$ Food Security Multisectoral Program of Togo (ProSecAl Togo), Togo \\ *Email: etchihal@gmail.com
}

Submitted: 16 March 2020. Revised: 26 April 2020. Accepted: 1 June 2020

\begin{abstract}
Roots and tubers are one of the most important crops that provide food security in West Africa. Thus, Pachyrhisus erosus with its various potentials, is planned to be introduced in Benin to improve the nutritional quality of the population. Prior to that, this study aimed at assessing pests and disease of P. erosus in the agroecological conditions in the central parts of Benin. Conducted at experimental field in Savè during two consecutive years, experiments were laid in a completely randomized block design with 4 replications and three treatments including EC 533 and EC Kew cultivars of $P$. erosus and cowpea variety named Kpodji-Guèguè. Results showed that the major pests collected from P. erosus namely Ootheca mutabilis, Medythia quaterna, Piezotrachelus varium, Megalurothrips sjostedti and Brevipalpus phoenis were not so far reported in it. Compared to cowpea, pest's infestation and their damages were lower on P. erosus. Infestation severity on leaves and the percentage of perforated green pods ranged from $0.7 \%$ to $3 \%$ against $0.8 \%$ to $88.9 \%$ and from $12.5 \%$ to $16 \%$ against $57.2 \%$ to $64 \%$ respectively on P. erosus and cowpea. Cercospora disease caused by Cercospora canescens and yam bean leaf blight caused by an unknown fungus were observed. Cercospora disease affected cowpea and $P$. erosus while yam bean leaf blight affected only P. erosus. This study provides additional data on pests and diseases associated with $P$. erosus worldwide and alerts farmers regarding their management.
\end{abstract}

Key words: Benin; Diseases; Pachyrhizus erosus; Pests; Yam Bean

How to Cite: Bouraïma, A., Sikirou, R., Zocli, B., Ezin, V., Etchiha Afoha, S. A. P., Gnancadja, L. S., Adjanonhoun, A., \& Hell, K. (2020). Pests and Diseases Associated with Yam Bean (Pachyrhizus erosus) Cultivation at Farmers' Levels in the Central Region of Benin. Biosaintifika: Journal of Biology \& Biology Education, 12 (2), 132-139

DOI: http://dx.doi.org/10.15294/biosaintifika.v12i2.23771

\section{INTRODUCTION}

Worldwide, root and tuber crops play an important role among edible plants. They rank third after cereals and grain legumes and are the staple food for over $20 \%$ of the world population (FAOSTAT, 2010). According to Sharma \& Kaushal (2016), these crops contribute significantly to sustainable development, income generation and food security, especially in the tropical regions. Pachyrhizus spp., commonly called yam bean is a root legume originating from Central America and South Caribbean (Adjahossou, 2006). It is an underutilized legume crop in the tropics and subtropics (Jacobsen et al., 2015).

The genus includes five species, of which two are wild and three are cultivated types (Reddy, 2015). Among the cultivated species, P. erosus is the one of which the roots accumulate reserve substances (Zanklan, 2003). According to More et al. (2019), it is one of the only 15 species with edible tubers among 50,000 edible plants grown in the world.

$P$. erosus is a traditional medicinal plant grown in tropical and subtropical regions (Kumalasari et al., 2014). Its tuber extracts have beneficial effects on human health, including cardiovascular benefits, inhibition of $\alpha$-glucosidase activity, and antitumor properties (Thaptimthong et al., 2016). A functional property of its starch is similar to those of cassava starch allowing it to be used as a potential new source of starch (Mélo et al., 2003). According to Noman et al. (2006), the micro- and macro-nutrient analysis revealed the $P$. erosus tuber to be potential source of potassium, sodium, phosphorus, calcium and magnesium and could be included in dietary formulae for man or monogastric animals, especially in those areas where carbohydrate is in short supply. Its storage root is usually consumed fresh after removal of the thick, fibrous brown skin and the taste resembles that of Chinese water chestnut (Silva et al., 2016). The young 
tuber can also be eaten cooked or pickled (Reddy, 2015). Zanklan et al. (2007) reported the possibility to process its gari (produced by fermentation of grated pulp, followed by dehydration, sieving and roasting) like that of cassava which is consumed daily by millions of people. Comparing P. erosus tubers processed singly and mixed with cassava into different types of gari following the traditional gari processing method, Padonou et al. (2013) demonstrated that the proteins content of the processed $P$. erosus tubers' garis increased with increasing incorporation rate of P. erosus.

This crop occupies a prominent place in traditional farming systems because of its ability to fix atmospheric nitrogen through symbiotic bacteria of root nodules (Fuentes et al., 2002). It improves the soil content in nitrogen by deposing 70 to $100 \mathrm{~kg}$ of nitrogen per hectare. Its tubers and other products are marketed and provide substantial income to farmers.

Despite its various potential uses, P. erosus until today is not yet an African crop (Andiku et al., 2019). Moreover, a number of insect pests and several diseases are reported to cause damage in $P$. erosus limiting this way, its performance (Reddy, 2015).

Due to the potential of $P$. erosus in nutrients, and in order to improve the nutritional quality of the Beninese population, the National Institute of Agricultural Research of Benin (INRAB) with the support of the International Potato Center (IPC) aim to introduce $P$. erosus in Benin. Legumes being generally very susceptible to pests and diseases, the knowledge of the reaction of $P$. erosus against pests and diseases from Benin agro-ecological zones is compulsory, prior to its introduction. The tudy aimed at assessing pests and diseases associated to P. erosus in agroecological conditions of central Benin. Results will provide additional data on pests and diseases associated with $P$. erosus worldwide and alert farmers regarding the management. The data are basic for scientists working on P. erosus.

\section{METHODS}

\section{Experimental site and design}

Trials were conducted in the forest-savanna zone on the experimental site of Gobé, at the Agricultural Research Center of the Central Benin (CRA/Centre/INRAB). It is characterized by a bimodal rainy season with rains from April to July and from August to September, with an annual average precipitation of $1214 \mathrm{~mm}$. During the experimental periods, the average rainfall was $680.3 \mathrm{~mm}$ and 442.9 $\mathrm{mm}$ for year 1 and 2 respectively. The soil is tropical ferruginous.

During two consecutive years, two cultivars of $P$. erosus (EC 533 and EC Kew) and one local cowpea variety (Kpodji Guèguè) were sown in a randomized complete block design replicated 4 times. Cowpea was sown at 60,000 plants/ha and P. erosus at a density of 12,000 plants/ha. To improve the nutritional quality of the soil, NPK (15-15-15) was added at the rate of $100 \mathrm{~kg} / \mathrm{ha}$. One month after sowing, the plants of $P$. erosus were staked. No pesticides were applied during the trials.

\section{Assessment of insect pests and infestation}

The population of pests was obtained by inventorying and counting from both crops, the number of observed insects through careful visual inspection of the aerial parts (leaves, stems, flowers, pods and seeds) of plants. Twenty plants were randomly selected on the two central rows per plot from vegetative to poding. At flowering, three flowers of ten plants were randomly examined per plant for the counting of associated pests. At poding, 20 green pods were randomly picked out from 10 plants and followed for 7 days at room temperature and dissected to assess emerging insects. From 20 dried pods per plot, healthy and infested seeds and associated insects as well were counted. All emerging insects were identified. Data were collected every 7 days from planting to poding. The incidence of damaged was calculated as the ratio of damaged plants to the total number of sampled plants (20 plants). The severity of damage was calculated as the ratio of leaves with holes on the total number of leaves per plant.

\section{Assessment of mite pests and damage}

The infested leaves of $P$. erosus and cowpea were collected and soaked in 70\% ethanol and transported to the acarology section of the International Institute of Tropical Agriculture, IITA Benin (IITA-Benin, c/o LW Lambourn \& Co. Croydon CR 9 3EE, UK) for identification. The incidence of the infested plants was calculated as the ratio of plants with mite symptoms on the total number of sampled plants (20 plants).

\section{Assessment of diseases and damage}

Aerial parts (collar, stems, and leaves) of selected plants were carefully observed every two weeks from $15^{\text {th }}$ day after sowing to poding. The disease incidences were calculated as the ratio of infected plants on the total number of sampled plants (20 plants). The severity of diseases was evaluated as the ratio of infected leaves on the total number of leaves per plant. In this case, 10 plants were assessed.

\section{Identification of pathogens}

Leaves showing symptoms were collected from each plot of both crops, placed in the newspapers and transported to the Laboratory of Crop Protection 
(LDC) at National Institute of Agricultural Research of Benin (INRAB) for isolation and identification of associated pathogens. In the laboratory, after washing, leaves were surface sterilized with $70 \%$ ethanol and rinsed with sterile distilled water. Leaf samples of about $4 \mathrm{~mm}^{2}$ were taken between the border line of healthy tissue and diseased tissue and then soaked for $10 \mathrm{~min}$ in a solution of $1 \%$ sodium hypochlorite. These samples were then rinsed 3 times with sterile distilled water and then dried under the laminar on sterilized filter paper. The dried fragments were plated on Potato Dextrose Agar (PDA) medium and incubated at $25^{\circ} \mathrm{C}$.

One week after incubation, the sprouted fungi were observed under light microscope and purified on PDA medium by single spore isolation. The color of mycelia, shape, size and the arrangement of spores or conidia on conidiophores were the used criteria of identification (Watanabe, 1994).

\section{The pathogenicity test}

The pathogenicity of the isolated fungi was performed by hyphal inoculation of leaflets of 6 weeks old age seedlings of $P$. erosus. Fifteen leaflets of each of both cultivars of $P$. erosus with three leaflets per plant were inoculated with mycelium of isolated fungi. The inoculation consisted of pricking each leaflet at three closed points with a sterilized pin. One pin was used per isolate. Pricked areas were covered with a piece of $2 \mathrm{~mm}^{2}$ of 10 days culture of each fungus taken from the edge of the colonies. The control leaflets were also wounded and covered with 2 $\mathrm{mm}^{2}$ of sterile PDA medium. After inoculation, plants were covered with a black polyethylene bags and placed at room temperature $\left( \pm 25^{\circ} \mathrm{C}\right)$ for 3 days.

\section{Statistical analysis}

ANOVA was performed using SAS program (SAS Institute Inc., Release 9.0., Cary, NC, USA) on the number of different insects, incidence of infested plants, severity of damaged plants, incidence of infested leaves by mites, diseases incidences, disease severities based on four replications with 10 to 20 plants each. The Student-Newman-Keuls test at 5\% was used to compare mean values of all variables. Values given in tables are means with corresponding standard errors.

\section{RESULTS AND DISCUSSION}

\section{Mean population of associated pests with $\mathrm{Pach}$ - yrhizus erosus and cowpea during the growing stage}

During the two consecutive years of the study, the beetles Ootheca mutabilis, Medythia quaterna (Figure
1), the aphid Aphis craccivora and the mite Brevipalpus phoenicis were observed during the growth stage of $P$. erosus and cowpea (Table 1). None of these insect pests have been so far reported on P. erosus but the possibility of $P$. erosus plants to be susceptible to insect pests with minor consideration to cause a serious damage on it had been reported (Reddy, 2015). Considering that the majority of those insects were reported as cowpea pests (Egho, 2011), their presence on P. erosus in the current study may be not only due to the fact that the both crops are in the same environment but also to the resemblance of their aerial part.

Analyses of variance carried out on the mean po- pulation of $O$. mutabilis and the number of plants with aphid and mite showed significant differences ( $P$ $<0.0001)$ between treatments during the two years. The population of $O$. mutabilis was high in cowpea plots and low in that of Pachyrhizus during the two consecutive years. Any A. craccivora was not observed on P. erosus plots during the two consecutive years but in cowpea, the number of plants harboring it was high. M. quaterna population was very low in both crops but more observed in cowpea plots during the first year. During the second trial, no significant difference was obtained between both crops $(\mathrm{P}=0.726)$. The low infestation and the low number of pest recorded in P. erosus is probably due to the repellent effect of this crop. The results also showed that the aphids could not survive or multiply during the two consecutive years on $P$. erosus. This can be due to the insecticidal effect of $P$. erosus on the aphids. In fact, rotenone is present in any other part of the plant (Sørensen, 1996).

The highest pest populations were recorded in cowpea. This confirm many results revealing that insect pests represent the major limiting factor of cowpea production in sub-Saharan Africa (Togola et al., 2017). The analysis of variance on the number of plants with Brevipalpus phoenicis showed a significant difference between treatments $(\mathrm{P}<0.0001)$. B. phoenicis infested both crops but was more severe on $P$. erosus (Figure 2) than on cowpea and its infestation was more remarkable during the second year. B. phoenicis has not been reported as cowpea pest so far. Its presence in our study in low population on cowpea can be due to the fact that it is a cosmopolitan and polyphagous mite (Laranjeira et al., 2015) and on $P$. erosus underpins the conclusions of Reddy (2015) who reported the possible presence of spider mites capable of transmitting disease to P. erosus. Moreover, its high population observed especially during the second year is due to the low rainfall quantity recorded because successive rain events decreases its infestation (Laranjeira et al., 2015). According to the authors, although they feed on many crops, the main damage is indirect via their transmission of several phytoviruses. Thus, to minimize the risk of its spread, $P$. erosus has to be cultivated in rain period. 


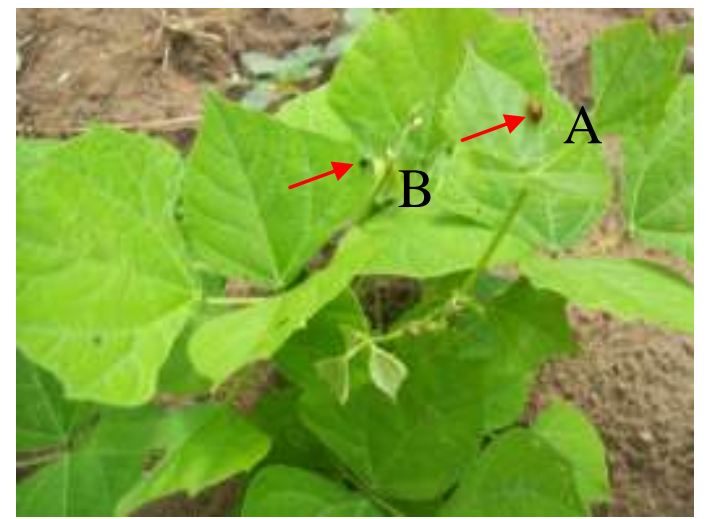

Figure 1. Ootheca mutabilis (A) and Medythia quaterna (B) on P. erosus at growing stage

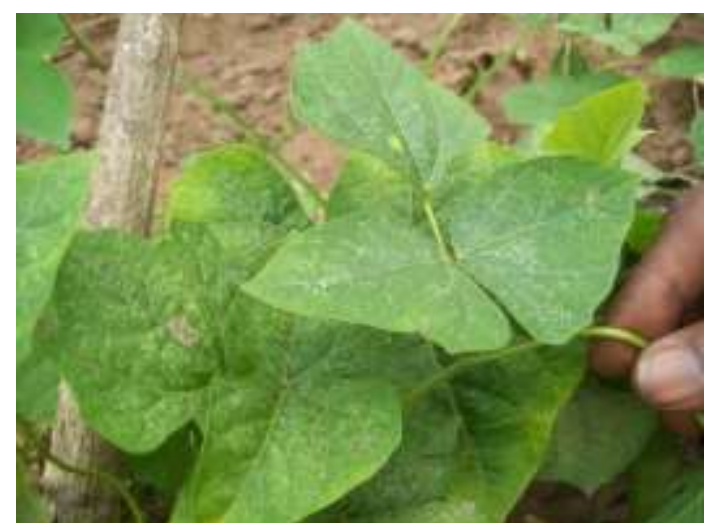

Figure 2. Leaves of $P$. erosus attacked by the mite Brevipalpus phoenis

Table 1. Mean population of associated pests with Pachyrhizus erosus and cowpea during the growing stage

\begin{tabular}{|c|c|c|c|c|c|}
\hline \multirow{2}{*}{ Parameters } & \multirow{2}{*}{ Years } & \multicolumn{3}{|c|}{ Crops } & \multirow{2}{*}{ Probabilities } \\
\hline & & EC 533 & EC Kew & Cowpea & \\
\hline \multirow{2}{*}{$\begin{array}{l}\text { Mean population of } \\
\text { Ootheca mutabilis }\end{array}$} & I & $0.01 \pm 0.11 b^{1}$ & $0.008 \pm 0.006 b$ & $0.68 \pm 0.09 \mathrm{a}$ & \multirow{3}{*}{$\mathrm{P}<0.0001$} \\
\hline & II & $0.03 \pm 0.007 b^{1}$ & $0.01 \pm 0.004 b$ & $0.98 \pm 0.014 \mathrm{a}$ & \\
\hline \multirow{2}{*}{$\begin{array}{l}\text { Mean population of } \\
\text { Medythia quaterna }\end{array}$} & I & $0.006 \pm 0.003 b^{1}$ & $0.011 \pm 0.004 a b$ & $0.023 \pm 0.005 a$ & \\
\hline & II & $0.003 \pm 0.002 \mathrm{a}^{1}$ & $0.00 \pm 0.00 \mathrm{a}$ & $0.003 \pm 0.003 a$ & $P=0.726$ \\
\hline \multirow{2}{*}{$\begin{array}{l}\text { Plants with Aphis } \\
\text { craccivora }(\%)\end{array}$} & I & $0.0 \pm 0.0 b^{2}$ & $0.0 \pm 0.0 \mathrm{~b}$ & $0.05 \pm 0.01 \mathrm{a}$ & \multirow{4}{*}{$\mathrm{P}<0.0001$} \\
\hline & II & $0.0 \pm 0.0 b^{2}$ & $0.0 \pm 0.0 \mathrm{~b}$ & $2.0 \pm 0.07 \mathrm{a}$ & \\
\hline \multirow{2}{*}{$\begin{array}{l}\text { Plants with Brevipal- } \\
\text { pus phoenicis }(\%)\end{array}$} & I & $0.58 \pm 0.031 b^{2}$ & $0.64 \pm 0.026 a$ & $0.00 \pm 0.00 \mathrm{c}$ & \\
\hline & II & $90.8 \pm 1.1 \mathrm{a}^{2}$ & $90.0 \pm 1.9 \mathrm{a}$ & $41.0 \pm 2.9 b$ & \\
\hline
\end{tabular}

${ }^{1}$ Mean of 80 repetitions. ${ }^{2}$ Mean of 12 repetitions. Means followed by the same letters in the same column are not significantly different according to Student-Newmann-Keuls test with $\mathrm{P}=0.05$

Mean population of associated pests with Pachyrhizus erosus and cowpea during the flowering

During the two consecutive years, the mean population of Megalurothrips sjostedti was significantly different $(\mathrm{P}<0.0001)$ in the flowers of cowpea and of $P$. erosus (Table 2). During the second year, $M$. sjostedti was noticed on $100 \%$ of inspected flowers for cowpea and for $P$. erosus with a significantly high mean comparatively to the first year where its population was low in the both crops' flowers. The low population of $M$. sjostedti during the first year is due to the high quantity of rainfall recorded during the flowering. The rains have reduced the proliferation of $M$. sjostedti. In the second year and during the flowe ring, a very low quantity of rainfall which allowed $M$. sjostedti's proliferation was recorded. These results are in line with those of Norris et al. (2002) who re- ported that rainfall duration significantly decreased the numbers of thrips remaining on the plants.

Table 2. Mean population of Megalurothrips sjostedti in flowers of Pachyrhizus erosus and cowpea

\begin{tabular}{lcc}
\hline \multirow{2}{*}{ Crops } & \multicolumn{2}{c}{$\begin{array}{c}\text { Mean population of } \text { M. sjostedti per } \\
\text { flower }\end{array}$} \\
\cline { 2 - 3 } & Year I & Year II \\
\hline EC 533 & $0.55 \pm 0.024 \mathrm{a}^{1}$ & $5.2 \pm 0.00 \mathrm{~b}^{1}$ \\
EC Kew & $0.43 \pm 0.028 \mathrm{~b}$ & $4.6 \pm 0.14 \mathrm{c}$ \\
Cowpea & $0.29 \pm 0.027 \mathrm{c}$ & $5.7 \pm 0.16 \mathrm{a}$ \\
\hline Probabilities & $\mathrm{P}<0.0001$ & $\mathrm{P}<0.0001$ \\
\hline${ }^{1}$ Mean of 40 repetitions. Means followed by the same \\
letters in the same column are not significantly differ- \\
ent according to Student-Newmann-Keuls test with \\
$\mathrm{P}=0.05$
\end{tabular}




\section{Damage of Pachyrhizus erosus and cowpea pests on leaves}

The damage of pests on $P$. erosus and cowpea characterized by the leaves punching (Figure 3 ) of the two crops was more severe during the second year compared to the first (Table 3). The percentage of perforated leaves was significantly lower on $P$. erosus during the two consecutive years $(\mathrm{P}<0.0001)$. About $90 \%$ of cowpea leaves were perforated by insects against less than $3 \%$ for $P$. erosus. This low damage on $P$. erosus leaves is due to the low population of insects recorded during the two consecutive years of the experiment. Furthermore, the presence of the rose beetle (Adoretus versutus) that reported as a serious leaf destroyer in P. erosus (Khan et al., 2013) was not noted.

\section{Health status of Pachyrhizus erosus and cowpea pods and seeds}

The percentage of the perforated green pods (Figure 4) was significantly low in P. erosus plots comparatively to cowpea plots where it was very high ( $\mathrm{P}<0.0001)$ (Table 4). From the green pods of cowpea and P. erosus, Piezotrachelus varium was record-

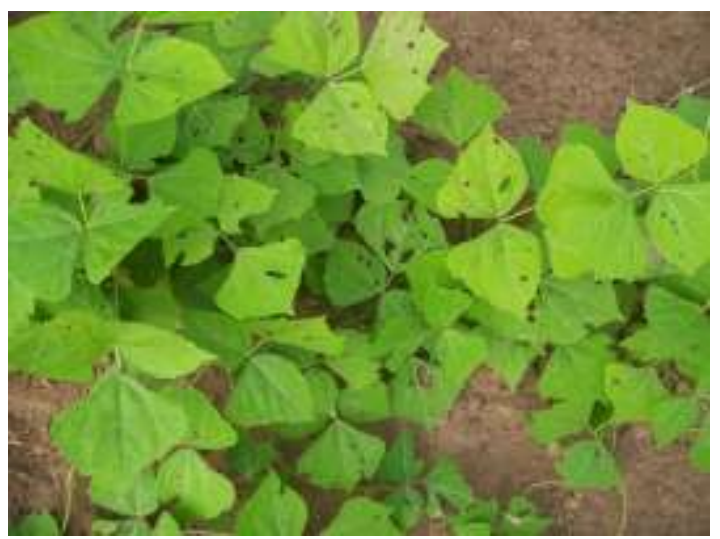

Figure 3. Damage of Ootheca mutabilis and Medythia quaterna on $P$. erosus at growing stage ed. It was less abundant in green pods of $P$. erosus than in that of cowpea. The low perforated green pods are due to the low population of $P$. varium retrieved from them. But from the dried pods of both crops, only Acanthomia horrida was recorded in cowpea and during the first year (Table 4).

Table 3. Infestation severity on Pachyrhizus erosus and cowpea leaves caused by Pests

\begin{tabular}{lcc}
\hline \multirow{2}{*}{ Crop } & \multicolumn{2}{c}{ Damage severity $(\%)$} \\
\cline { 2 - 3 } & \multicolumn{1}{c}{ Year I } & Year II \\
\hline EC 533 & $0.72 \pm 0.01 \mathrm{~b}^{1}$ & $2.9 \pm 0.6 \mathrm{~b}$ \\
EC Kew & $0.76 \pm 0.01 \mathrm{~b}$ & $2.2 \pm 0.8 \mathrm{~b}$ \\
Cowpea & $0.83 \pm 0.02 \mathrm{a}$ & $88.9 \pm 11.1 \mathrm{a}$ \\
\hline Probabilities & $\mathrm{P}<0.0001$ & $\mathrm{P}<0.0001$ \\
\hline
\end{tabular}

${ }^{1}$ Mean of 40 repetitions. Means followed by the same letters in the same column are not significantly different according to Student-Newmann-Keuls test with $\mathrm{P}=0.05$

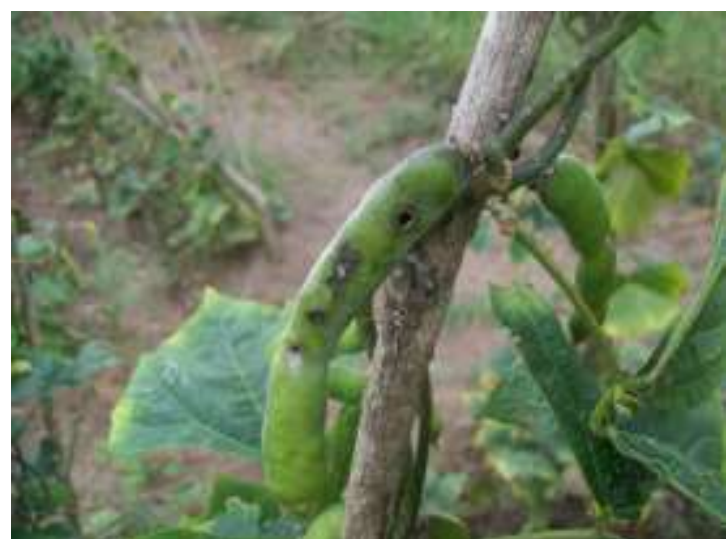

Figure 4. $P$. erosus paods attacked by Piezotrachelus varium

Table 4. Perforated cowpea and Pachyrhizus erosus pods by Acanthomia horrida and Piezotrachelus varium

\begin{tabular}{lccccc}
\hline \multirow{2}{*}{ Crops } & \multicolumn{2}{c}{ Perforated green pods $(\%)$} & \multicolumn{2}{c}{ P. varium population } & A. horrida population \\
\cline { 2 - 6 } & Year I & Year II & Year I & Year II & Year I \\
\hline EC 533 & $12.5 \pm 1.2 \mathrm{~b}^{1}$ & $16.0 \pm 1 \mathrm{~b}^{1}$ & $0.95 \pm 1 \mathrm{~b}^{1}$ & $0.6 \pm 0.24 \mathrm{~b}$ & $0 \pm 0 \mathrm{~b}^{1}$ \\
EC Kew & $14.7 \pm 2.8 \mathrm{~b}$ & $12.7 \pm 1.6 \mathrm{~b}$ & $0.6 \pm 1.6 \mathrm{~b}$ & $0.95 \pm 0.46 \mathrm{~b}$ & $0 \pm 0 \mathrm{~b}$ \\
Cowpea & $57.2 \pm 5.2 \mathrm{a}$ & $64.0 \pm 4.5 \mathrm{a}$ & $43.15 \pm 4.5 \mathrm{a}$ & $43.15 \pm 5.42 \mathrm{a}$ & $58.9 \pm 0.8 \mathrm{a}$ \\
\hline Probabilities & $\mathrm{P}<0.0001$ & $\mathrm{P}<0.0001$ & $\mathrm{P}<0.0001$ & $\mathrm{P}<0.0001$ & $\mathrm{P}<0.0001$ \\
\hline
\end{tabular}

${ }^{1}$ Means of 40 replications; Means followed by the same letters in the same column are not significantly different according to Student-Newmann-Keuls test with $\mathrm{P}=0.05$

During the two consecutive years, the perforated seeds were significantly low in $P$. erosus dried pods than in that of cowpea $(\mathrm{P}<0.0001)$ (Table 5). This is probably due to the highest amount of endogenous rotenone present in the mature seeds as reported by
Reddy (2015). According to this author, old pods and mature seeds can be poisonous. In the current study, bruchids reported as the serious pests endangering $P$. erosus cultivation (Sørensen, 1996) were not observed. 
Table 5. Perforated and distorted cowpea and Pachirhyzus erosus seeds (\%)

\begin{tabular}{lcc}
\hline \multirow{2}{*}{ Crops } & \multicolumn{2}{c}{ Perforated seeds (\%) } \\
\cline { 2 - 3 } & Year I & Year II \\
\hline EC 533 & $1.67 \pm 0.80 \mathrm{~b}^{1}$ & $2.54 \pm 1.17 \mathrm{~b}^{1}$ \\
EC Kew & $1.16 \pm 0.48 \mathrm{~b}$ & $2.91 \pm 1.52 \mathrm{~b}$ \\
Cowpea & $39.80 \pm 5.38 \mathrm{a}$ & $11.08 \pm 4.5 \mathrm{a}$ \\
\hline Probabilities & $\mathrm{P}<0.0001$ & $\mathrm{P}<0.0001$
\end{tabular}

${ }^{\mathrm{T}}$ Means of 40 replications; Means followed by the same letters in the same column are not significantly different according to Student-Newmann-Keuls test with $\mathrm{P}=0.05$

\section{Identification of associated diseases with Pachyrhi- zus erosus and cowpea}

Several fungi have been reported to cause severe damage in P. erosus (Reddy, 2015). During the two consecutive years, two different diseases characterized by leaf spot and leaf blight symptoms were observed on P. erosus (Figure 5).

The leaf spot symptoms are characterized by brown circular necrotic spots of 5 to $8 \mathrm{~mm}$ in diameter with yellowish-brown border. From the isolated specimens, blackish mycelium with hyaline brown conidiophores and very elongated hyaline and many septate conidia were observed 10 days after incuba- tion. Based on its morphological characteristics (Pirnia, 2014), the fungus was identified as Cercospora canescens which has already been reported on P. erosus in India (Mohanty \& Bahera, 1961).

According to the leaf blight, symptoms are characterized at early stage by a large yellowing of the leaf margin followed by a wide lesion of varying sizes moving from leaf tip inwardly. When the attack is severe, the margins of the whole leaf blighted. The inside of the lesions are small and very hard black balls more or less round. These bodies look like sclerotia and come from the arrangements of the mycelium. The colony of the fungus causing the disease showed a black mycelium. When each of the two fungi were separately re-inoculated to healthy plants of $P$. erosus, they developed 7 days after inoculation, similar symptoms as those observed in the field, while plants inoculated with only agar as control showed no symptoms. For the both fungi, Koch's postulates were confirmed by their re-isolation from artificially inoculated plants. Apart from these two fungi reported on P. erosus in this study, Alternaria dauci, Chaetoseptoria wellmanii, Erysiphe communis, Erysiphe polygon, Leveillula taurica, Phaeoisariopsis griseola were also reported as pathogens of P. erosus (Kahn \& Lima, 2001).

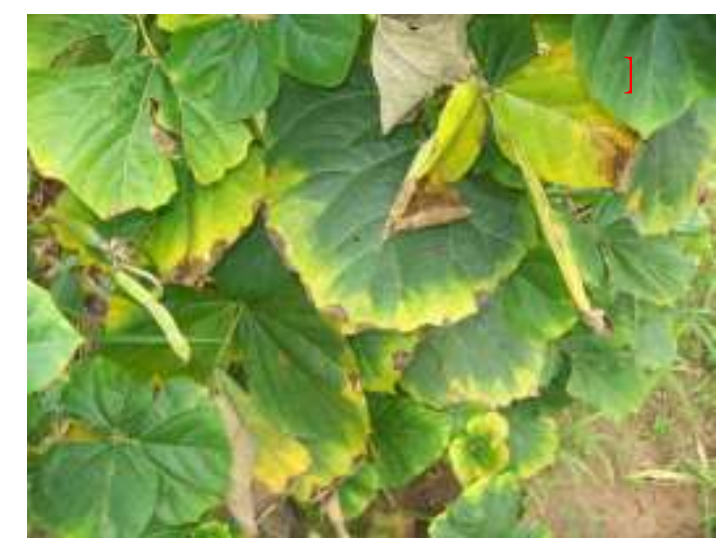

(B) on leaves of P. erosus

less susceptible to $C$. canescens than Cowpea. According to the disease's severity, the same trends as their incidences were noted. Cercospora disease was significantly higher in cowpea plots and low in $P$. erosus plots during the second year $(\mathrm{P}<0.0001)$. The cercospora disease was less severe on $P$. erosus than on cowpea and the leaf blight was more severe on $P$. erosus and absent on cowpea. This result confirms those of Bohra et al. (2013), who reported cowpea to be adversely affected by a wide range of fungal diseases among which, cercospora leaf spot caused by $C$. canescens. 
Table 6. Incidence and severity of cercospora and leaf blight disease on Pachyrhizus erosus and cowpea

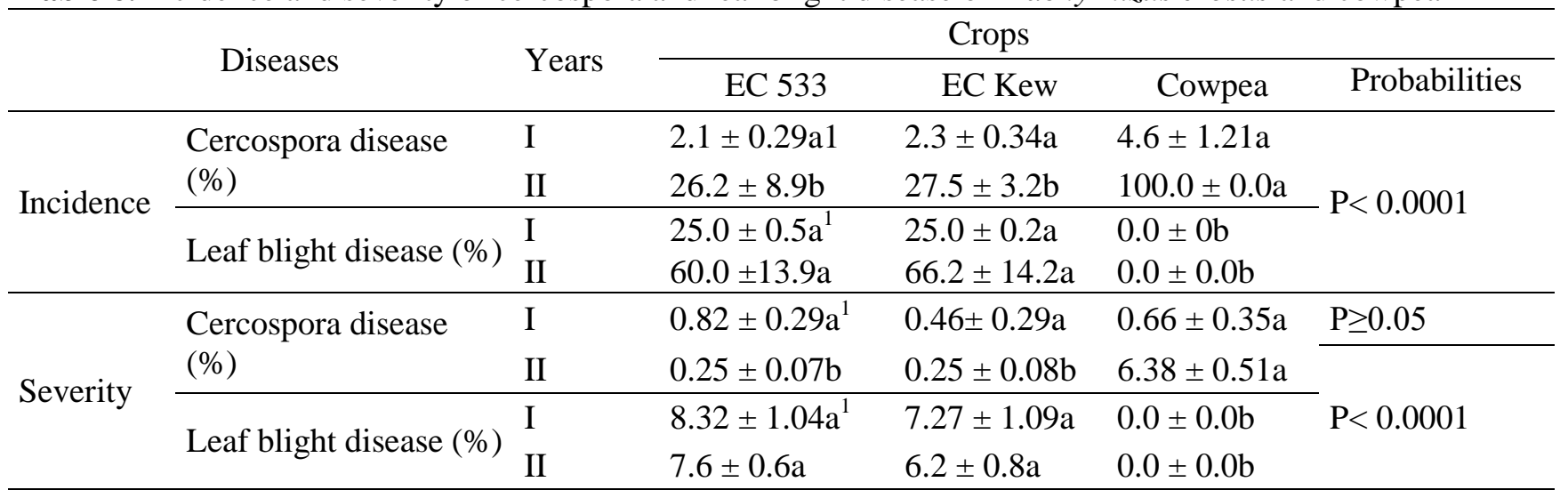

${ }^{1}$ Mean of 40 replications. Means followed by the same letters in the same column are not significantly different according to Student-Newmann-Keuls test with $\mathrm{P}=0.05$

The current study reports for the first time Ootheca mutabilis, Medythia quaterna, Piezotrachelus varium, Megalurothrips sjostedti and Brevipalpus phoenis as associated pests with $P$. erosus. Thus, it provides additional data on pests and diseases associated with $P$. erosus worldwide and alerts farmers regarding their management as these pests constitute a serious constraints of cowpea in tropical countries and especially in Benin.

\section{CONCLUSION}

This study results that $P$. erosus is less infested by insects than cowpea. O. mutabilis, M. quaterna, $P$. varium, M. sjostedti and B. phoenicis were the collected pests. According to disease, Cercospora leaf spot caused by $C$. canescens and leaf blight caused by an unidentified fungus were observed on P. erosus which is more susceptible to leaf blight disease than to cercospora disease.

\section{ACKNOWLEGEMENTS}

The authors thank the International Potato Center (IPC) for financing the study and are grateful to $\mathrm{Dr}$ Ignace Dossa Zannou posthumously for the identification of Brevipalpus phoenicis.

\section{REFERENCES}

Adjahossou, D.F. (2006). Ablation des inflorescences et rendement en tubercules chez le haricot igname mexicain (Pachyrhizus erosus). Notes de recherche. Cah. Agric., 15(2), 213-219.

Andiku, C., Tukamuhabwa, P., Ssebuliba, J. M., Talwana, H., Tumwegamire, S., \& Grüneberg, W. J. (2019). Evaluation of the American yam bean (Pachyrhizus spp.) for storage root yield across varying eco-geographic conditions in Uganda. Journal of Agricultural Science, 11(8), 100-112.
Bohra, A., Jha, U.C., Singh, B., Soren, K.R., Singh, I.P., Chaturvedi, S.K., Nadarajan, N., \& Barh, D. (2013). Omics Approaches in Pulses. In: D. Barh (Ed.), OMICS: Applications in Crop Science (pp.101-138). New York: CRC Press/Taylor \& Francis Group.

Egho, E.O. (2011). Management of major field insect pests and yield of cowpea (Vigna unguiculata (L) walp) under calendar and monitored application of synthetic chemicals in Asaba, southern Nigeria. American Journal of Scientific and Industrial Research, 2(4), 592-602.

FAOSTAT. (2010). Database of FAO (Food and Agriculture Organization). Retrieved from www.fao.org

Fuentes, J.B., Abe, M., Uchiumi, T., Suzuki, A., \& Higashi, S. (2002). Symbiotic root nodule bacteria isolated from yam bean (Pachyrhizus erosus). J. Gen. Appl. Microbiol., 48, 181-191.

Jacobsen, S.E., Sørensen, M., Pedersen, S.M., \& Weiner, J. (2015). Using our agrobiodiversity: Plant-based solutions to feed the world. Agronomy for Sustainable Development, 35(4), 1217-1235.

Kahn, R.P., \& Lima, P. (2001). Importation of YamBean or Jícama Roots (Pachyrhizus spp. Rich. ex DC., Nom. Cons.) from El Salvador, Honduras and Nicaragua into the Continental United States: A Qualitative, Pathway-Initiated Risk Assessment. USA: Animal and Plant Health Inspection Service. Retrieved from http://www.bio-nica.info/bibliote ca/Kahn2001Pachyrhizus.pdf.

Khan, D., Sahito, Z.A., \& Ahmad, I. (2013). The occurrence of White Grub [Adoretus versutus Harold 1869] in the sandy rhizosphere of Acacia nilotica Subsp. Nilotica seedlings irrigated with moderately saline water. Int. J. Biol. Biotech., 10(2), 319-325.

Kumalasari, I.D., Nishi, K., Harmayani, E., Raharjo, S., \& Sugahara, T. (2014). Immunomodulatory activity of Bengkoang (Pachyrhizus erosus) fiber ex- 
tract in vitro and in vivo. Cytotechnology, 66, 7585.

Laranjeira, F.F., de Brito Silva, S.X., de Andrade, E.C., de Oliveira Almeida, D., da Silva, T.S.M., Soares, A.C.F., \& Freitas-Astua, J. (2015). Infestation dynamics of Brevipalpus phoenicis (Geijskes) (Acari: Tenuipalpidae) in citrus orchards as affected by edaphic and climatic variables. Experimental and Applied Acarology, 66, 491-508.

Mélo, E.A., Stamford, T.L.M., Silva, M.P.C., Krieger, N., \& Stamford, N.P. (2003). Functional properties of yam bean (Pachyrhizus erosus) starch. Bioresource Technology, 89, 103-106.

Mohanty N.N., \& Behera B.C. (1961). Leaf spot of Pachyhizus angulatus Rich. Sci. Nat., 27(5), 54.

More S.J., Ravi, V., \& Saravanan, R. (2019). Tropical tuber crops. In: S.T. de Freitas \& S. Pareek (Eds.), Postharvest physiological disorders in fruits and vegetables. New York: CRC Press/Taylor \& Francis Group, 721-757.

Noman, A.S.M., Hoque, M.A., Haque, M.M., Pervin, F., \& Karim, M.R. (2006). Nutritional and antinutritional components in Pachyrhizus erosus L. tuber. Food Chemistry, 102, 1112-1118.

Norris, R.J., Memmott, J., \& Lovell, D.J. (2002). The effect of rainfall on the survivorship and establishment of a biocontrol agent. Journal of Applied Ecology, 39, 226-234.

Padonou, S.W., Hounyèvou, A.K., Ahounou, J.L., Houssou, A.P., Fandohan, P., Aïhou, K., Adjanohoun, A., Hell, K., Adégbola, P.Y., Mensah, G.A., \& Koudandé, D.O. (2013). Yam bean (Pachyrhizus erosus) tuber processing in Benin: production and evaluation of the quality of yam bean-gari and yam bean-fortified gari. Int. J. Biol. Chem. Sci., 7(1), 247-259.

Pirnia, M. (2014). Additions and corrections to names published in Cercospora in Iran. Mycologia Iranica 1(2), 65-74.
Reddy, P.P. (2015). Plant Protection in Tropical Root and Tuber Crops. India: Springer.

Sharma, H. K., \& Kaushal, P. (2016). Introduction to Tropical Roots and Tubers. In: H.K. Sharma, N.Y. Njintang, R.S. Singhal \& P. Kaushal (Eds.), Tropical Roots and Tubers: Production, Processing and Technology. UK: John Wiley \& Sons, Ltd, 1-33.

Silva, E. S., Silva Filho, D. F., \& Ticona-Benavente, C. A. (2016). Diversity of yam bean (Pachyrhizus spp. Fabaceae) based on morphoagronomic traits in the Brazilian Amazon. Acta Amaz, 46(3), 233240.

Thaptimthong, T., Kasemsuk, T., Sibmooh, N., \& Unchern, S. (2016). Platelet inhibitory effects of juices from Pachyrhizus erosus L root and Psidium guajava L fruit: a randomized controlled trial in healthy volunteers. BMC Complement Altern. Med., 16, 269.

Togola A., Boukar O., Belko N., Chamarthi S. K., Fatokun C., Tamo M., \& Oigiangbe N. (2017). Host plant resistance to insect pests of cowpea (Vigna unguiculata L. Walp.): achievements and future prospects, Euphytica, 213-239.

Watanabe, T. (1994). Pictorial Atlas of Soil and Seed Fungi. Morphologies of cultured Fungi and Key to species. USA: Lewis Publishers.

Zanklan, A. S. (2003). Agronomic performance and genetic diversity of the root crop yam bean (Pachyrhizus spp.) under West African conditions (Doctoral dissertation). Faculty of Agricultural Sciences. Germany: Georg-August University of Göttingen.

Zanklan, A. S., Ahouangonou, S., Heiko, C. B., Pawelzik, E., \& Grünebergd, J. W. (2007). Evaluation of the Storage Root-Forming Legume Yam Bean (Pachyrhizus spp.) under West African Conditions. Crop Sci., 47, 1934-1946. 